Volume 9, No.1.4, 2020

International Journal of Advanced Trends in Computer Science and Engineering

Available Online at http://www.warse.org/IJATCSE/static/pdf/file/ijatcse5191.42020.pdf

https://doi.org/10.30534/ijatcse/2020/5191.42020

\title{
Chemical Effect on the Mechanical Properties of Bamboo Fiber for Textile: A review
}

\author{
Muslihah Mokeramin ${ }^{1}$, Mohd Nazrul Roslan ${ }^{1 *}$, Azrin Hani Abdul Rashid ${ }^{1}$, Siti Hana Nasir ${ }^{1}$, \\ Juliana Abdul Halip ${ }^{2}$ \\ ${ }^{1}$ Faculty of Engineering Technology, Universiti Tun Hussein Onn Malaysia 86400 Batu Pahat, Johor, Malaysia, \\ nazrul@uthm.edu.my*,azrin@uthm.edu.my, sitihana@uthm.edu.my, \\ ${ }^{2}$ Faculty of Technology Management and Business, Universiti Tun Hussein Onn Malaysia 86400 Batu Pahat, Johor, Malaysia, \\ julianaah@uthm.edu.my
}

\begin{abstract}
The needs on sustainable fiber of bamboo for textile and non-textile materials are never being doubt. The mechanical properties of bamboo fibers are unique among their species. Thus, this fiber requires a unique process to be implemented in order to meet their application. Often, previous studies had adopted various fiber extraction and treatment yet these processing were affected their physical and mechanical properties. Chemical treatments are often being applied onto natural fibers such as bamboo in order to improve crucial properties subjected to textile processing capability. Specifically, the treatment partially removes the cellulosic and non-cellulosic contents of the bamboo fiber bundle such as hemicellulose, lignin and pectin. An appropriate concentration of alkaline usage in treating bamboo fiber could obtain the optimum mechanical and physical performance along with the changes of its surface morphological. This paper provides a brief review on the published reports concerning on anatomical, chemical composition and physical of bamboo. The effect of alkaline treatment on bamboo fibers have been discussed and reviewed in terms of their mechanical behavior and physical properties.
\end{abstract}

Key words: Chemical treatment; Bamboo fiber; Mechanical properties; Textile.

\section{INTRODUCTION}

The utilization of natural fiber in textile material has never ending over the years of studies. The revolution in the plantation by adopting an advanced method i.e. IoT [1], [2] also secures the natural fibre resources as textile materials. Either to replace or reduce the consumption of synthetic fiber, the increasing demands of this eco-friendly materials are the ultimate reason besides the exceptional quality offered and the environmental awareness. Common natural plant fibers adopted in textile are bamboo, ramie, sisal, coir, cotton, flax, pineapple, and jute. Among these fibers, bamboo is not been commercialized in textile application.

Bamboo is an abundance plant commonly to be found in South America, Middle East, and Asia. Table 1 shows several species with different genera that have been found in Asia region [3]. Bamboo has become in-trend these days as non-timber forest resources as it commonly utilized by rural communities in shaping world needs especially for food, medicinal uses, construction materials, and human crafts. To date, bamboo is adopted on the non-traditional application such as scaffolding structure, composite material, and textile. Particularly, bamboo fiber is recognized to have unique properties applicable to be manufactured into apparel products as well as technical textile products [4], [5]. Bamboo textile imposes inflated demand due to its aseptic nature, decomposable, hygroscopic, softness and UV protection as well as breathability, quick drying, good thermoregulatory, high durability, supply maximum comfortability, stability and tenacity to the wearer which were applied in the bedding products, underwear, t-shirts, socks blankets and proven to have softer qualities than cotton and silk [6], [7].

Widely reported that bamboo has variety of physical properties over variety of species and genera family had been found [8], [9]. Most of research studies conducted on fiber properties concluded that bamboo has short length and fine diameter approximately 2 to $4 \mathrm{~mm}$ and $0.02 \mathrm{~mm}$ respectively [8], [10]. Particularly in market product, bamboo textile embedded regenerated fiber in making yarn. Generally, this process requires short fibers or pulp processing before dissolve and extrude into filament yarn. However, this process is not truly green, and the final product consider as man-made. In order to extract a long fiber of bamboo or fiber bundle, various methods could be found. Green processing approaches were suggested similar process of flax fiber. This approach implies mechanical method as well as chemical. Chemical method is the easiest and fastest process yet affected bamboo fiber bundle properties.

In-depth knowledge is important to be understand particularly on chemical processing of bamboo fiber bundle structure. Therefore, this study is about a brief review on the basis of anatomical, chemical composition and physical of bamboo. In addition, the effects of chemical processing on physical and mechanical properties of bamboo fibers associated to green textile processing are reviewed. In the end 
of this review, surface morphological of bamboo are discussed as well.

Table 1: Species, Genera and Forest area of bamboo plant in several countries [3]

\begin{tabular}{|c|c|c|c|}
\hline Country & Species & Genera & Area $\left.\mathbf{( k m}^{\mathbf{2}}\right)$ \\
\hline China & 500 & 40 & 61,586 \\
\hline India & 136 & 23 & 108,630 \\
\hline Myanmar & 100 & 17 & 8,950 \\
\hline Thailand & 60 & 13 & 8,100 \\
\hline Bangladesh & 30 & 13 & 863 \\
\hline Cambodia & 10 & 4 & 2,870 \\
\hline Vietnam & 101 & 15 & 10,000 \\
\hline Malaysia & 44 & 7 & 5,920 \\
\hline Philippines & 55 & 12 & 1,560 \\
\hline Japan & 230 & 13 & 1,413 \\
\hline
\end{tabular}

\section{BAMBOO SPECIES, ANATOMY, CHEMICAL COMPOSITION AND PHYSICAL FIBER CHARACTERIZATION}

Bamboo plants belong in the grass family, Poaceae with its taxonomically classified as Bambusoidea which could grew over $30 \mathrm{~m}$ in height only in a few months with the ability to survive the harshest climate condition of frost and delicate drought [11], [12]. Bamboo is categorized as perennial plants which require no re-planting after cultivation and promotes sustainability, regular culms harvesting as well as providing stable wage for manufacturer with low plantation investments besides eliminating the needs of pesticides nor chemical fertilizers resulting in cost-effectiveness naturally organic plant [13], [14]. Bamboo fibers aligned within the lignin matrix in a tube-like, hollow internal shape in between nodes [15] with the longitudinal, radial and tangential directions of the plant as shown in Figure 1. Natural bamboo fiber cultivated from its stem associated with vascular bundles implanted in its parenchyma tissue as illustrated in Figure 2 when treated by chemical and mechanical means can have the average length of $2.8 \mathrm{~mm}$ with average diameter of $20 \mu \mathrm{m}$ [7], [8], [9].

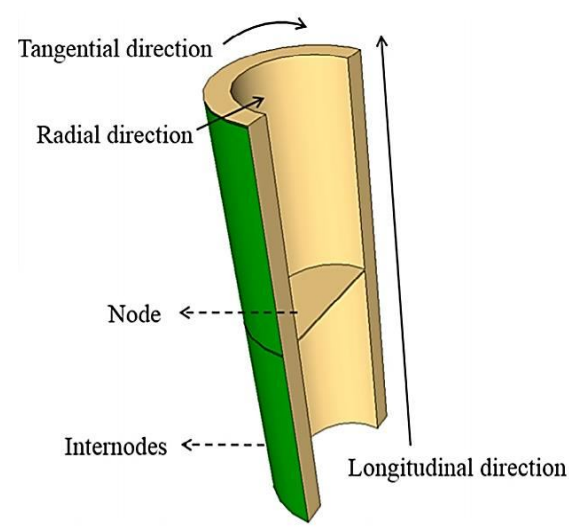

Figure 1: Structure of bamboo [16]

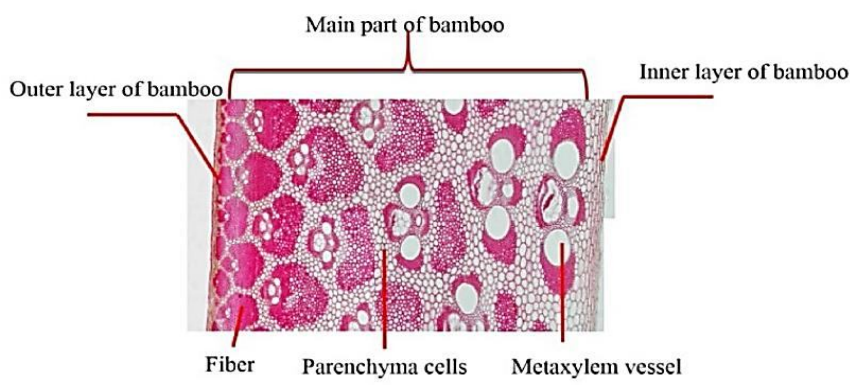

Figure 2: Bamboo plant anatomy [15]

Akinlabi et. al (2017) [6] reported chemical content of cellulose, hemicellulose and lignin approximate 70\%, 12\% and 10\% respectively. Razak et. al (2013) [9] compared four commercialized Malaysian bamboo associated to chemical composition. The varies of bamboo species were found varies significant chemical composition of holocelulose ranging from $74 \%$ to $85 \%$ while in between of bamboo section nodes and internodes presented varies values as well. In contrast on Fengel \& Shao (1984) [18] study, bamboo contained chemical composition of $25 \%$ lignin, $25-30 \%$ hemicellulose and $40-45 \%$ cellulose in which nanograin cellulose structures were revealed as the basic elements of bamboo fiber cell walls [19]. Comparing between similar bast fibers jute and flax, chemical composition of bamboo has similiarity between them [17].

Table 2: Chemical composition of between natural bast fibers [17]

\begin{tabular}{|c|c|c|c|}
\hline Chemical component (\%) & Bamboo & Jute & Flax \\
\hline Aqueous extract content & 3.16 & 3.06 & 5.74 \\
\hline Pectin content & 0.37 & 1.72 & 1.81 \\
\hline Hemicellulose content & 12.49 & 13.53 & 11.62 \\
\hline Lignin content & 10.15 & 13.30 & 2.78 \\
\hline Cellulose content & 73.83 & 68.39 & 78.05 \\
\hline
\end{tabular}

In textile processing, spinning is the heart of yarn manufacturing. Spin ability of fiber rely on concern physical properties such as strenght, fineness, crimp, uniformity etc. As presented in Yueping et. al (2010) [17] study, bamboo fiber met initial requirement to spin due to its size and tensile strength as well as the high cellulose content after the alkali treatment as shown in Table 2. This study compared three different bast fibers; bamboo, jute and flax which was revealed fiber bundle of bamboo has better spin ability properties than jute yet lower properties of fineness than flax as shown in Table 3.

Table 3: Comparison bast fibers physical properties [17]

\begin{tabular}{|c|c|c|c|}
\hline Item & Bamboo* $^{*}$ & Jute & Flax \\
\hline Fineness/tex & 2.58 & 3.01 & 0.30 \\
\hline Length/mm & $70-90$ & $60-100$ & $10-25$ \\
\hline Strength/CN.dtex ${ }^{-1}$ & 4.8 & 4.60 & 4.78 \\
\hline *fiber bundle
\end{tabular}




\section{CHEMICAL TREATMENT FOR BAMBOO FIBER PROPERTIES}

Treatment on natural fiber is necessary in order to ensure the fiber produced is homogeneous and ready to be spun into textile products. Often, fiber treatments are divided into three main categories namely mechanical, physical and combined treatment. Chemical treatment is the most standard treatment for natural fibers to help in improving their mechanical and physical properties and to prepare the fiber to the next textile processing with improved fiber quality with re-engineered properties in order to compete with synthetic fiber for spinning process [13], [20] .

Chemical treatment is a process where the fiber surface is permanently modified by polymers grafting, bulking or cross-linking within cell wall [21]. Chemical treatment can be divided into acid and alkali treatment. Nitric acid is one of the acidic solutions used in acidic treatment on fiber [22]. Alkaline treatment or also known as mercerization is the most common treatment to be applied on natural fiber which helps breaking down the fiber bundle into individual fibers by immersing the fibers into a known concentration of hydroxides include Potassium hydroxide $(\mathrm{KOH})$ and sodium hydroxide $(\mathrm{NaOH})$ as its fundamental work resulting in the changes in its chemical nature, increase in roughness topography and degree of crystallinity by mechanism interaction between hydroxyl group, natural fibers and $\mathrm{NaOH}$ with water molecule as its excess product [23], [24]:

Fiber $-\mathrm{OH}+\mathrm{NaOH}$ - fiber $-\mathrm{O}^{-} \mathrm{Na}^{+}+\mathrm{H} 2 \mathrm{O}+$ impurities

Bleaching treatment on the other hand was usually applied in post-processing of alkaline treatment for removing lignin content from partial lignin removal of prior alkaline treatment [24]. In others application, Shuhimi et al., (2017) [25] stated the effectiveness of chemical treatment on natural fiber reinforced composite effected better wear performance, reduced porosity as well as enhancing fiber-matrix interfacial adhesion through improved adhesion, hydration and internal curing process. In addition, its help eliminating impurities and modified the surface morphology of fibers chemically [26]. According to Roslan et al., (2018) [27], chemical treatment helps to impose the hydrophobicity properties on natural fiber by limiting the possibility of chemical components such as cellulose, hemicellulose, lignin and wax content from attracting the water molecule that might lead to deprivation of mechanical properties of bamboo fiber. Moreover the chemical treatment such as alkaline solution Sodium Hydroxide $(\mathrm{NaOH})$ on bamboo must be applied in controlled concentration as fiber treated with excessive alkaline concentration revealed to be deteriorated in strength due to unnecessary removal of lignin and hemicellulose [28].

\section{MECHANICAL PERFORMANCE OF BAMBOO FIBER}

Tensile experiment is usually performed on bamboo fiber to identify and analyse the mechanical performance [29]. Table 4 summarized on difference studies had been conducted associated to chemicals used on bamboo fiber surface treatment. As discussed previously, chemical treatment processing consists of variable parameters such as concentration, temperature and duration. These parameters were affecting the physical and mechanical properties of bamboo fiber.

Kaur et al., (2013) [20] found the alkaline treatment of aged 2 to 3 years bamboo with the concentration of $5 \%, 10 \%, 15 \%$, $20 \%$ and $25 \% \mathrm{Na} 2 \mathrm{SO} 3$ and $0.5 \%$ Lissapol D for 45 minutes shows the minimum loss of lignin in bamboo fiber which clearly reveals the reduction in non-cellulosic materials.

Osorio et al., (2011) [30] conducted a single fiber tensile experiment on bamboo species Guadua angustifolia at four different span lengths with manipulated alkali concentration treatment of $0 \%, 1 \%, 3 \%$ and $5 \% \mathrm{NaOH}$ for 20 minutes revealed the optimum result of $800 \mathrm{Mpa}$ and Young's modulus value of $43 \mathrm{GPa}$ for $3 \% \mathrm{NaOH}$ treated bamboo fiber resulted from waxes and lignin removals due to increased fiber strength and stiffness which led to attenuation of frail non-cellulosic materials. Hong et al., (2011) [31] explored the effects of various alkali treatments (Nitric Acid and potassium chloride, $\mathrm{HNO} 3+\mathrm{KClO} 3$; sodium hypochlorite, $\mathrm{NaClO}$; hydrogen peroxide and glacial acetic acid, $\mathrm{H} 2 \mathrm{O} 2+\mathrm{HAC}$; and sodium hydroxide, $\mathrm{NaOH}$ ) on single bamboo fibers species Neeeosinocalamus affinis has revealed that hydrogen peroxide and glacial acetic acid, $\mathrm{H} 2 \mathrm{O} 2+\mathrm{HAC}$ has maximum tensile strength of $1.78 \mathrm{GPa}$ for ultrasonic untreated bamboo fibers which followed by $\mathrm{NaOH}, \mathrm{HNO} 3+\mathrm{KClO} 3$ and $\mathrm{NaClO}$ with respective $1.52 \mathrm{GPa}, 1.32 \mathrm{GPa}$ and $1.30 \mathrm{GPa}$.

Chen et al., (2015) [32] manufactured different isolations of single bamboo fiber treated by chemical and mechanical means has discovered that chemically treated single bamboo fiber with $30 \%$ of hydrogen peroxide, distrilled water, and glacial acetic acid appeared to have stronger tensile strength at $1.77 \mathrm{GPa}$ compared to $0.93 \mathrm{GPa}$ for mechanically treated bamboo fiber. This was due to increase in fracture resistant by aggregated cellulose fibrils connected with each other in longitudinal direction during the cellulose degradation phase. Wang and Chen (2016) [33] supported this statement by confirming that single bamboo fiber treated with chemical solution (sodium sulphite, Na2SO3) showed the highest tensile strength and modulus of elasticity (MOE) at $1770 \mathrm{MPa}$ following by mechanical separation, vascular bundle mechanical separation, untreated bundle fiber and untreated bamboo strip. This proposed that bamboo's mechanical 
properties decreased as bamboo unit size increased due to weak interfaces of bamboo fiber middle lamella and fiber damaged by sample preparation and treatment.

A dedicated work by Yu et al., (2011) [34] was performed mi-cro-tensile test on bamboo fiber chemically isolated with hydrogen peroxide and glacial acetic acid revealed the tensile strength of bamboo fibers at average value of $1.56 \mathrm{GPa}$ with tensile elastic modulus at average of $33.03 \mathrm{GPa}$. This paper correlated with paper by Wang and Chen (2016) [33] which suggested that single bamboo fiber has higher tensile strength than bamboo fiber bundles as bamboo fiber bundles would reduce its loading capacity during tension application during debonding of fibers resulting in weaker tensile strength.

In contrast, Shao et al., (2010) [35] investigated the tensile strength of bamboo block and bamboo fiber bundle treated with mixed solution of $10 \%$ hydrogen peroxide and $10 \%$ glacial acetic acid at equal volume which displayed lower tensile strength of bamboo fiber bundle at $482.2 \mathrm{MPa}$ which was $18 \%$ less than bam-boo block due to its single tissue inefficient to pass loads and dispense stress loaded on vascular bundle unlike parenchymatous ground tissue embedded bamboo block besides possible damage on fiber bundles during separation process.

While, Yan, Chouw \& Yuan (2012) [36] performed tensile test on fiber single-strand yarns of different natural fibers (flax, linen and bamboo) extracted from woven fabric before immersing in 5\% wt $\mathrm{NaOH}$ solution according to standard test ASTM D2256. The result showed that the alkali treatment has caused in reduction of tensile value at $46.8 \mathrm{MPa}$ compared to untreated fiber at $67.5 \mathrm{MPa}$ might due to chemical reaction with $\mathrm{NaOH}$ caused the fiber deterioration by changing the cellulose chemical structure from crystalline cellulose I to amorphous cellulose II as well as diminution of stress transfer among fibrils. This was supported by a research by Chen et al., (2017) [37] on the effect of sodium hydroxide solution, $\mathrm{NaOH}$ at varying concentration of $6,8,10,15$ and $25 \%$ onto individual bamboo fibers after immersing in $1: 1 ; 30 \%$ Hydrogen peroxide : glacial acetic acid solution which has concluded that as the concentration of $\mathrm{NaOH}$ increased, the tensile strength and elasticity modulus (MOE) of bamboo fiber decreased but showed significant increase in the elongation at break of the fibers by $232 \%$ and $221 \%$ at $15 \%$ and $25 \% \mathrm{NaOH}$-treated bamboo fiber as compared to untreated samples. This suggested the strong $\mathrm{NaOH}$ treatment although caused in decline of tensile strength due to the damage on bamboo fine fibers upon gradual hemicellulose removal but transformed the fiber from brittleness into ductility during phase-changing cellulose I into II making it fit for textile processing.
Table 4: Chemical treatment on bamboo fibers associated to different studies

\begin{tabular}{|c|c|c|c|}
\hline $\begin{array}{l}\text { Name of } \\
\text { treatment }\end{array}$ & Chemical (s) used & Concentration & Ref. \\
\hline $\begin{array}{c}\text { Alkali } \\
\text { treatment }\end{array}$ & $\begin{array}{c}\text { Sodium sulphite } \\
(\mathrm{Na} 2 \mathrm{SO} 3) \\
\text { Lissapol D }\end{array}$ & $\begin{array}{c}5 \%, 10 \% \\
15 \%, 20 \% \\
25 \% \\
0.5 \% \\
\end{array}$ & [20] \\
\hline $\begin{array}{c}\text { Alkali } \\
\text { treatment }\end{array}$ & $\begin{array}{c}\text { Sodium hydroxide } \\
(\mathrm{NaOH})\end{array}$ & $\begin{array}{c}0 \%, 1 \%, 3 \% \\
5 \%\end{array}$ & [30] \\
\hline $\begin{array}{c}\text { Alkali } \\
\text { treatment }\end{array}$ & $\begin{array}{c}\text { Nitric Acid and } \\
\text { potassium chloride } \\
(\mathrm{HNO} 3+\mathrm{KClO} 3), \\
\text { sodium hypochlorite } \\
(\mathrm{NaClO}), \text { hydrogen } \\
\text { peroxide and glacial } \\
\text { acetic acid ( } \mathrm{H} 2 \mathrm{O} 2+ \\
\mathrm{HAC}) \text {, and sodium } \\
\text { hydroxide }(\mathrm{NaOH})\end{array}$ & $\begin{array}{r}65 \% \mathrm{HNO} 3 \\
+5 \% \mathrm{KClO} 3\end{array}$ & [31] \\
\hline $\begin{array}{c}\text { Alkali } \\
\text { treatment }\end{array}$ & $\begin{array}{c}\text { Hydrogen } \\
\text { peroxide and glacial } \\
\text { acetic acid }\end{array}$ & $\begin{array}{c}30 \% \mathrm{H} 2 \mathrm{O} 2,5 \\
\text { parts glacial } \\
\text { acetic acid }\end{array}$ & [32] \\
\hline $\begin{array}{c}\text { Alkali } \\
\text { treatment }\end{array}$ & $\begin{array}{c}\text { Sodium sulphite } \\
(\mathrm{Na} 2 \mathrm{SO} 3)\end{array}$ & - & {$[33]$} \\
\hline $\begin{array}{c}\text { Alkali } \\
\text { treatment }\end{array}$ & $\begin{array}{c}\text { Hydrogen } \\
\text { peroxide and glacial } \\
\text { acetic acid }\end{array}$ & - & [34] \\
\hline $\begin{array}{c}\text { Alkali } \\
\text { treatment }\end{array}$ & $\begin{array}{c}\text { Hydrogen } \\
\text { peroxide and glacial } \\
\text { acetic acid }\end{array}$ & $\begin{array}{c}10 \% \mathrm{H} 2 \mathrm{O} 2: \\
10 \% \text { glacial } \\
\text { acetic acid }\end{array}$ & {$[35]$} \\
\hline $\begin{array}{c}\text { Alkali } \\
\text { treatment }\end{array}$ & $\begin{array}{c}\text { Sodium hydroxide } \\
(\mathrm{NaOH})\end{array}$ & $5 \% \mathrm{wt}$ & {$[36]$} \\
\hline $\begin{array}{c}\text { Alkali } \\
\text { treatment }\end{array}$ & $\begin{array}{l}\text { Sodium hydroxide } \\
(\mathrm{NaOH})\end{array}$ & $\begin{array}{c}6 \%, 8 \%, 10 \% \\
15 \%, 25 \% \\
\end{array}$ & [37] \\
\hline
\end{tabular}

\section{SURFACE MORPHOLOGY}

Scanning Electron Microscopy (SEM) is commonly adapted on the study of morphological state of natural fiber such as bamboo fiber by analysing micro surfaces by means of high-resolution image analysis [38]. Alkaline treatment was usually applied to natural plant to remove its chemical constituents such as lignin and hemicellulose which its effect can also be evaluated from its surface morphology by Atomic Force Microscopy (AFM) technique which was showing the colour changes of the fiber due to breakdown of chemical bond as illustrated in Figure 3 [7]. Wang and Chen (2016) [33] confirmed the morphology of single bamboo fiber as a fiber with concentric circles multi-layered wall structure comprised of broad cell wall, small-scale lumen with some pits and a small microfibril angle. According to $\mathrm{Yu}$ et al., (2011) [34], vascular bundles responsible for the mechanical reinforcement are placed in the ground parenchyma matrix and denser towards the outer layer of culm wall as shown in Figure $4 \mathrm{a}$ and Figure $4 \mathrm{~b}$ with the existing of stiff and strong thick-walled fibers known as sclerenchyma fibers embedded within the parenchyma tissue as revealed by the SEM micrograph of bamboo fiber shown in Figure 4d and Figure 4c. 

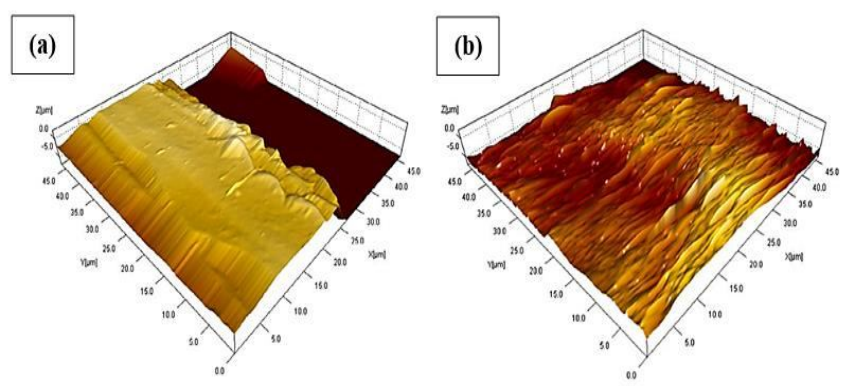

Figure 3: Color changes on surface morphology of bamboo fiber using AFM technique (a) Before and; (b) After alkaline treatment [7]
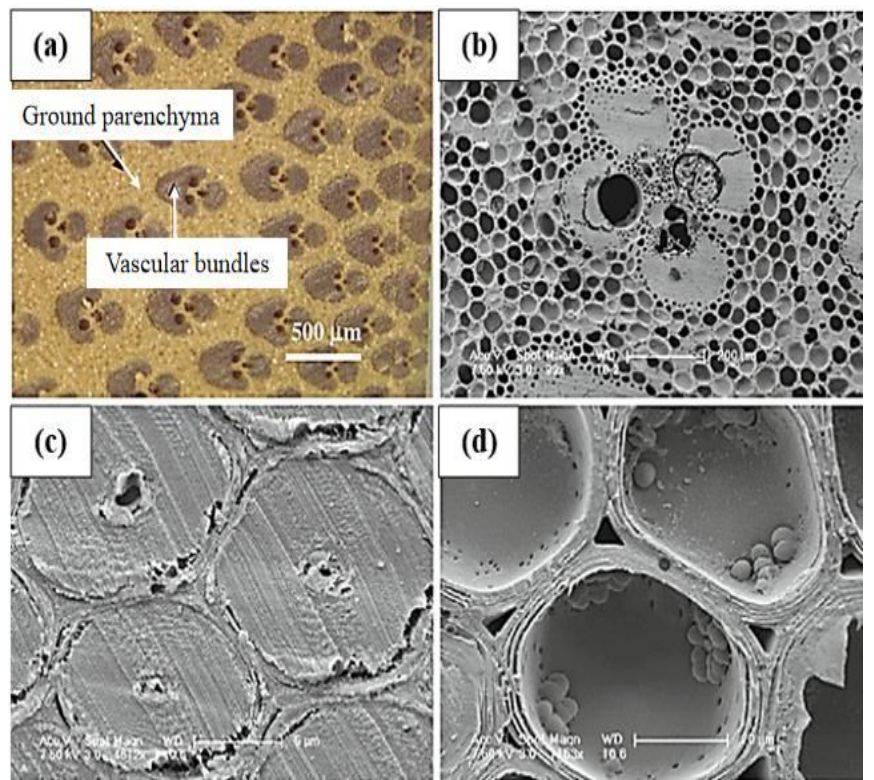

Figure 4: Transverse section of bamboo fiber showing: (a) vascular bundles graded distributions; (b) vascular bundles implanted in ground parenchymatous; (c) bamboo fibers; (d) parenchyma cells

[34]

Yan et al., (2012) [36] analyzed the microscopic vision of bamboo fibers treated with $5 \%$ wt $\mathrm{NaOH}$ using Scanning Electron Microscopy (SEM) has concluded that alkali treatment led to the decreased of density and diameter of single-strand yarns caused by fractional removal of linin, hemicellulose, and surface impurities which displayed more cleaner and rougher fiber surface as shown in Figure 5. Chen et al., (2017) [35] agreed to the fact that sodium hydroxide $(\mathrm{NaOH})$ treatment changed the physical appearance of bamboo fiber which was more distinct as the $\mathrm{NaOH}$ concentration increased from $6 \%, 8 \%, 10 \%, 15 \%$ and $25 \%$ by decreasing its diameter, lumen and cross sectional area due to depletion of matrix and microfibrils aggregation besides apparent disclosure of wrinkles and pores observed on its surface area by the scanning electron microscopy (SEM). Then, Chen et al., (2015) [30] analyzed the environmental scanning electron microscopy (ESEM) on bamboo fiber treated with a chemical solution of hydrogen peroxide and glacial acetic acid, suggesting that chemical treatment was superior to mechanical treatment due to the wider cross-sectional area of chemically treated bamboo fiber with no fracture on its surface fibers compared to mechanically treated bamboo fiber. Shao et al., (2010) [33] however revealed the scanning electron microscopy (SEM) micrograph of bamboo fiber treated with $10 \%$ hydrogen peroxide and $10 \%$ glacial acetic acid when performing tensile test showing the fracture behavior of the bamboo fiber in which the fracture surface of sclerenchyma fibers as well as its different layers of individual fibers were dense but rough as shown in respective Figure 6a in Figure 6c explaining the low tensile strength of the interface bond between individual layers of fiber and bamboo fibers generally.
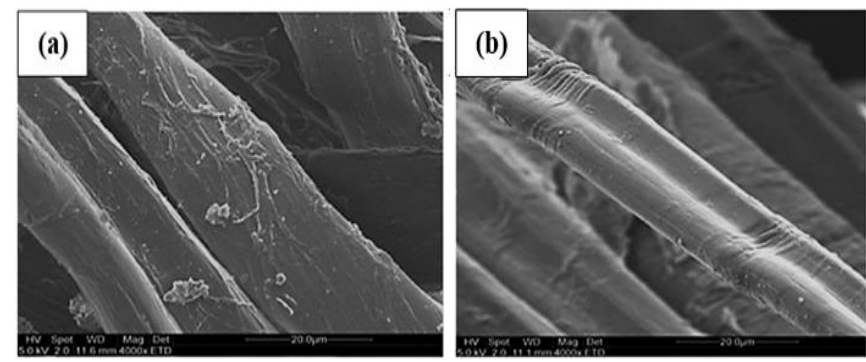

Figure 5: Surface morphology of bamboo fiber (a) Before and (b) After alkali treatment [36]
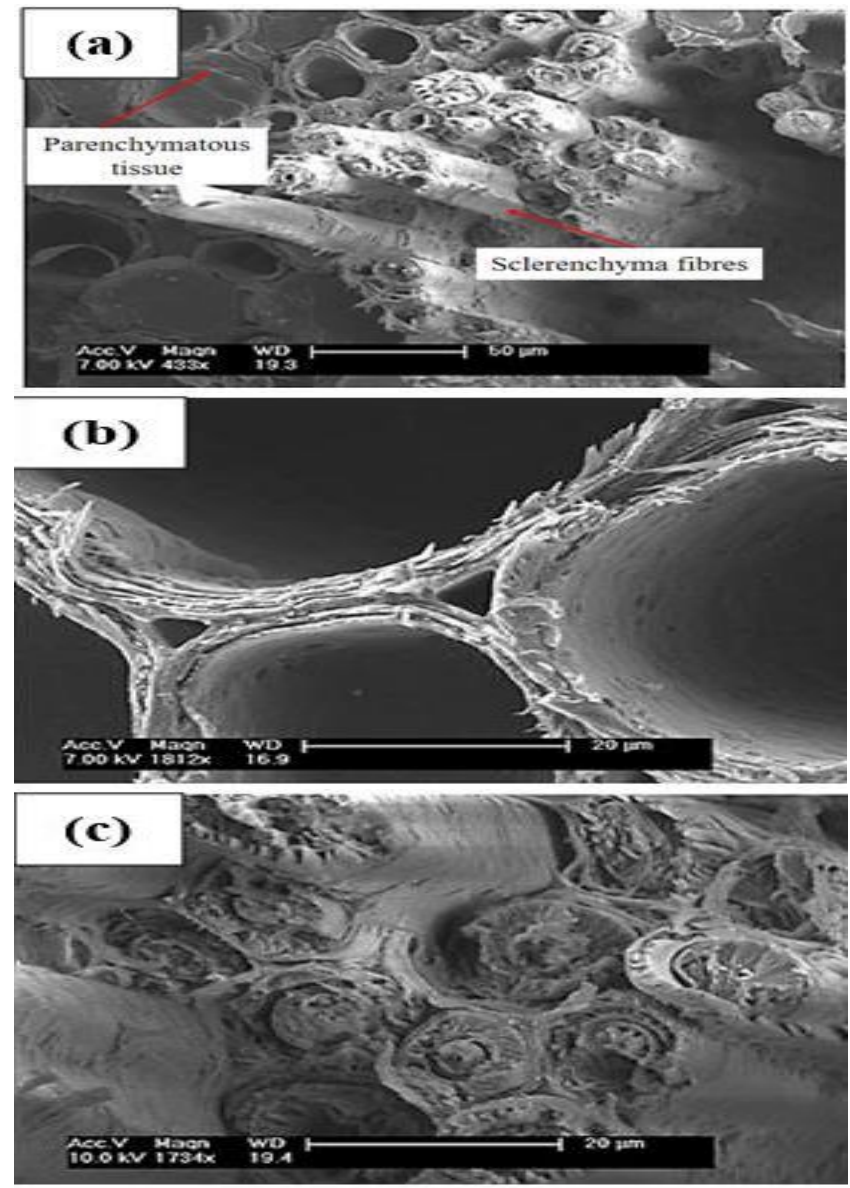

Figure 6: Micrographs of the fracture surface of bamboo fibers on:

(a) Parenchymatous tissue and sclerenchyma fibers; (b) parenchymatous tissue; (c) sclerenchyma fibers [35] 


\section{CONCLUSIONS}

This paper was intended to contribute in better understanding of anatomical, physical and chemical composition besides the effect of chemical treatment on the morphology and mechanical properties of bamboo fiber. The following main points can be remarked:

1. Bamboo are primarily composed of holocellulose, lignin, and hemicellulose in which any chemical alteration on the surface of fiber structure can disturb the mechanical behaviour of bamboo fiber.

2. Alkaline treatment improves mechanical properties of most bamboo fibers at optimal concentrations.

3. Although high concentration of alkali treatment decreased the tensile strength of bamboo fibers but increased the elongation at break transforming the fiber from brittleness into ductility making the fiber more attractive for textile applications.

4. Chemical treatment significantly improved the tensile and surface morphology of bamboo fiber compared to mechanical treatment

5. Most of single bamboo fiber has better tensile properties compared to bamboo fiber in a bundle form.

\section{ACKNOWLEDMENT}

The authors would like to thank the Malaysian Timber Industry Boad (MTIB), Ministry of Primaty Industry for supporting this research under Collaborative Research Grant Scheme Vot No. K252 and partially sponsored by Universiti Tun Hussein Onn Malatsia (UTHM)

\section{REFERENCES}

1. S. N. Z. Ahmmad, M. M. Jaafar, F. Muchtar, and M. I. Yusof. Automated Gardening Portable Plant Using IoT, International Journal of Advanced Trends in Computer Science and Engineering. Vol. 9(1,1), pp. 205-211, 2020.

https://doi.org/10.30534/ijatcse/2020/3691.12020

2. M. S. M. Zahid and N. N. A. Wahab. Plant Watering System using Mobile Application, International Journal of Advanced Trends in Computer Science and Engineering. Vol. 9(1,1), pp. 370-373, 2020.

3. Fei, B., Gao, Z., Wang, J., Liu, Z. Biological, Anatomical, and Chemical Characteristics of Bamboo, in Secondary Xylem Biology. Kim, Y. S., Singh, A. P., Funada, R., Amsterdam, the Netherlands: Elsevier,2016, pp. 283-306.

4. Li, S., Zheng, T., Li, Q., Hu, Y., Wang, B. Flexural and energy absorption properties of natural-fiber reinforced composites with a novel fabrication technique, Compos. Commun. 16, 124-131, 2019.

5. Waite, M. Sustainable textiles: The role of bamboo and a comparison of bamboo textile properties. $J$. Text. Apparel, Technol. Manag. Vol. 6, pp. 1-21, 2009.

6. Akinlabi, E.T., Anane-Fenin, K., Akwada, D.R.. Bamboo: The multipurpose plant, Springer, 2017. https://doi.org/10.1007/978-3-319-56808-9

7. Sánchez, M.L., Morales, L.Y., Caicedo, J.D. Physical and mechanical properties of agglomerated panels made from bamboo fiber and vegetable resin. Constr. Build. Mater. 156, 330-339, 2017.

8. Siam, N.A., Khairun, M., Uyup, A., Husain, H., Mohmod, A.L., Awalludin, M.F. Anatomical, Physical, and Mechanical Properties of Thirteen Malaysian Bamboo species. Bioresour. Technol. Vol. 14(2), pp. 3925-3943, 2019.

9. Wahab, R., Mustafa, M.T., Salam, M.A., Sudin, M., Samsi, H.W., Rasat, M.S.M. Chemical Composition of Four Cultivated Tropical Bamboo in Genus Gigantochloa. J. Agric. Sci. Vol. 5, pp. 66-75, 2013.

10. Youssefian, S., Rahbar, N. Molecular origin of strength and stiffness in bamboo fibrils. Sci. Rep. 5, pp. 1-13, 2015.

11. Dey, A., Chetia, N. Experimental study of Bamboo Reinforced Concrete beams having various frictional properties, in Materials Today Proc. Vol. 5, pp. 436-444, 2018.

12. Stapleton, C.M.A. The bamboos of nepal and bhutan part III: Drepanostachyum, Himalayacalamus, Ampelocalamus, Neomicrocalamus and Chimonobambusa (Gramineae: Poaceae, Bambusoideae). Edinburgh J. Bot., Vol. 51(3), pp. 301-330, 1994. https://doi.org/10.1017/S0960428600001815

13. Van Dam, J.E.G., Elbersen, H.W., Daza Montaño, C.M. Bamboo Production for Industrial Utilization. Perennial grasses for bioenergy and bioproducts 175-216, 2018.

14. Munjal, K., Kashyap, R. Bamboo Fiber: An Approach toward Sustainable Development. Int. J. Sci. Res. Vol. 4 (4), pp. 2319-7064, 2013.

15. Huang, Y., Ji, Y., Yu, W. Development of bamboo scrimber: a literature review. J. Wood Sci. 65, 2019.

16. Huang, P., Chang, W.S., Ansell, M.P., Chew, Y.M.J., Shea, A. Density distribution profile for internodes and nodes of Phyllostachys edulis (Moso bamboo) by computer tomography scanning. Constr. Build. Mater. Vol. 93, pp. 197-204, 2015.

17. Yueping, W., Ge, W., Haitao, C., Genlin, T., Zheng, L., Feng, X.Q., Xiangqi, Z., Xiaojun, H., Xushan, G. Structures of Bamboo Fiber for Textiles. Text. Res. J. Vol. 80, pp. 334-343, 2010.

18. Fengel, D., Shao, X. A chemical and ultrastructural study of the Bamboo species Phyllostachys makinoi Hay. Wood Sci. Technol. Vol. 18, pp. 103-112, 1984.

19. Zou, L., Jin, H., Lu, W.Y., Li, X. Nanoscale structural 
and mechanical characterization of the cell wall of bamboo fibers. Mater. Sci. Eng. C. Vol. 29(4), pp. 1375-1379, 2009.

20. Kaur, V., Chattopadhyay, D.P., Kaur, S. Study on Extraction of Bamboo Fibres from Raw Bamboo Fibres Bundles Using Different Retting Techniques. Text. Light Ind. Sci. Technol. Vol. 2(4), pp. 174-179, 2013.

21. Buson, R.F., Melo, L.F.L., Oliveira, M.N., Rangel, G.A.V.P., Deus, E.P. Physical and mechanical characterization of surface treated bamboo fibers. Sci. Technol. Mater. 1-7, 2018.

22. Taloub, N., Liu, L., Du, Y., Rahoui, N., Huang, Y. Surface modification of PIPD fiber using nitric acid treatment. Surf. Coatings Technol. Vol. 334, pp. 312-318, 2018.

23. Jones, D., Ormondroyd, G.O., Curling, S.F., Popescu, C.M., Popescu, M.C. Chemical compositions of natural fibres. Advanced High Strength Natural Fibre Composites in Construction. Fan M., Fu F., Elsevier Science, 2016, ch.2, pp. 23-58.

24. Abdellaoui, H., Raji, M., Essabir, H., Bouhfid, R., Qaiss, A. el kacem. Mechanical behavior of carbon/natural fiber-based hybrid composites. Mech. Phys. Test. Biocomposites, Fibre-Reinforced Compos. Hybrid Compos, $1^{\text {st }}$ ed., Jawaid M., Thariq M., Saba N., Elsevier, 2018, ch.7, pp. 103-122.

25. Shuhimi, F.F., Abdollah, M.F. Bin, Kalam, M.A., Masjuki, H.H., Mustafa, A., Mat Kamal, S.E., Amiruddin, H. Effect of operating parameters and chemical treatment on the tribological performance of natural fiber composites: A review. Part. Sci. Technol. Vol. 35(5), pp. 512-524, 2017.

26. Mahzabin, M.S., Hock, L.J., Hossain, M.S., Kang, L.S. The influence of addition of treated kenaf fibre in the production and properties of fibre reinforced foamed composite. Constr. Build. Mater. Vol. 178, pp. 518-528, 2018.

27. Roslan, S.A.H., Hassan, M.Z., Rasid, Z.A., Ibrahim, H.I. Tensile behaviour of chemical treatment for bamboo epoxy composites. Chem. Eng. Trans. Vol. 63, 745-750, 2018.

28. Omid, N., Sujan, D., Jack, K.B., Mohammad, Y.A. Mechanical performance and moisture absorption of unidirectional bamboo fiber polyester composite. Mater. Sci. Forum. Vol. 911, pp. 88-94, 2018.

29. Norazlina, H., Fahmi, A.R.M., Hafizuddin, W.M. CaCO from seashells as a reinforcing filler for natural rubber. J. Mech. Eng. Sci. Vol. 8, pp. 1481-1488, 2015 https://doi.org/10.15282/jmes.8.2015.22.0144.

30. Osorio, L., Trujillo, E., Van Vuure, A.W., Verpoest, I. Morphological aspects and mechanical properties of single bamboo fibers and flexural characterization of bamboo/ epoxy composites. J. Reinf. Plast. Compos. Vol. 30, pp. 396-408, 2011.

31. Hong, C., Ge, W., Hai-Tao, C. Properties of single bamboo fibers isolated by different chemical methods. Wood Fiber Sci. Vol. 43, pp. 111-120, 2011.

32. Chen, H., Cheng, H., Wang, G., Yu, Z., Shi, S.Q. Tensile properties of bamboo in different sizes. J. Wood Sci. Vol. 61, pp. 552-561, 2015.

33. Wang, G., Chen, F. Development of bamboo fiber-based composites. Adv. High Strength Nat. Fibre Compos. Constr. Fan M., Fu F., Elsevier Science, 2016, ch.2, pp. 235-255.

34. Yu, Y., Jiang, Z., Fei, B., Wang, G., Wang, H. An improved microtensile technique for mechanical characterization of short plant fibers: A case study on bamboo fibers. J. Mater. Sci. Vol. 46, pp. 739-746, 2011.

35. Shao, Z.P., Fang, C.H., Huang, S.X., Tian, G.L. Tensile properties of Moso bamboo (Phyllostachys pubescens) and its components with respect to its fiber-reinforced composite structure. Wood Sci. Technol. Vol. 44, pp. 655-666, 2010.

36. Yan, L., Chouw, N., Yuan, X. Improving the mechanical properties of natural fibre fabric reinforced epoxy composites by alkali treatment. $J$. Reinf. Plast. Compos. Vol. 31, pp. 425-437, 2012.

37. Chen, H., Yu, Y., Zhong, T., Wu, Y., Li, Y., Wu, Z., Fei, B. Effect of alkali treatment on microstructure and mechanical properties of individual bamboo fibers. Cellulose. Vol. 24(1), 333-347, 2017. https://doi.org/10.1007/s10570-016-1116-6

38. Sajjala, K., Kala, F. Bamboo Fibre Analysis By Scanning Int. J. Civ. Eng. Technol. vol. 7, pp. 234-241, 2016. 